быстро обмениваться информацией, а информация, как известно, в наше время поставлена во главу угла. По законам нового времени успеха быстрее добивается тот, кто раньше становится владельцем новой информации. «Кто владеет информацией, тот владеет миром»,- говорил Н. Ротшильд.[14]

$$
* * *
$$

1. Berges Emilie. 2011. L'utilisation du SMS chez l'adolescentdyslexique, dysorthographique. Mémoired'orthophonie : $\quad$ Franche-Comté, [Электронныйресурc], Режимдоступа:https://celestehenry2.wordpress.com

2. LaureAckermann. Le cyberlangageetl'influencesur l'ecritureconventionnelle. Education. 2013.[Электронный ресурс], Режим доступа:https://celestehenry2.wordpress.com

3. Liénard Fabien. 2014. La langue françaisemenacée par les SMS ?. Dossier pour la science, janvier-mars 2014, n82, p. 116-118, [Электронныйресурс], Режимдоступа:http://www.pourlascience.fr/ewb_pages/a/article-lalangue-francaise-menacee-par-les-span-style-text-transform-uppercase-sms-span-32516.php

4. Mia KjærJessenLe langage chat et SMS est-ilune menace pour l'usagetraditionnel de la langue ?Mémoire de licence (http://pure.au.dk/portal/files/40539879/217761.pdf)

5. Racimora Maria-Léna. 2012. De l'universtélévisuel à la feuilleblanche :quels liens ? Mémoired'orthophonie : Nice, [Электронныйресурс], Режимдоступа:https://celestehenry2.wordpress.com

6. Simoës-Perlant, A. 2012. Le langageécrit et sestroubles :apports des nouveaux supports de communication. A.N.A.E., septembre 2012, Volume 24, Tome III, n¹18, p. 257-388, [Электронныйресурс], Режимдоступа:https://celestehenry2.wordpress.com

7. Weck Geneviève de, Marro Pascale. 2010. Les troubles du langage chez l'enfant : Description et évaluation. Masson, [Электронныйресурс], Режимдоступа:https://www.elsevier-masson.fr/les-troubles-du-langage-chezlenfant-9782294707599.html

8. Бекова Э.Ю. Лингвистические аспекты виртуальной коммуникации во французском языке [Электронный ресурс]/ Э.Ю. Бекова//. Режим доступа:http://открытыйурок.рф/статьи/623671/

9. Ефимова О.В. Фундаментальные основы современного машинного перевода в свете общей теории переводческой деятельности. // Научные исследования и современное образование. Сборник материалов Международной научно-практической конференции. Редколлегия: О.Н. Широков [и др.]. Чебоксары, 2017. С. 205-212.

10. Примеры кодированных слов СМС-языка https://autodidacteblog.wordpress.com/2016/07/26/langage-sms/

11. Примеры кодированных слов CMC-языка https://vk.com/topic-19989728_24850713

12. Сидоров А.А. Формы молодежного общения и их влияние на состояние современного французского $\begin{array}{lllll}\text { языка. } \quad \text { [Электронный } & \text { ресурс]/ } & \text { A.A. } & \text { Сидоров// } & \text { 2011Режим }\end{array}$ доступа:http://www.volsu.ru/upload/medialibrary/fef/4_iucepakisiqbii.pdf

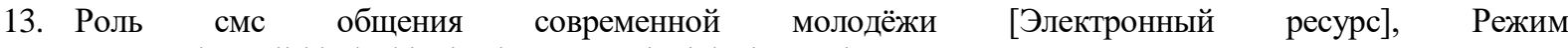
доступа:https://shkolazhizni.ru/computers/articles/75218/

14. https://ru.wikipedia.org/wiki/Ротшильды

\title{
Островная Ю.М. \\ К вопросу о происхождении косметической терминологии (на материале русского и французского языков)
}

Белгородский государственный национальный исследовательский университет (Россия, Белгород)

doi: 10.18411/lj-30-11-2017-27

idsp: 000001:lj-30-11-2017-27

\section{Аннотация}

Статья посвящена этимологическому анализу косметических терминов, употребляемых в сфере женской косметологии русскими и французскими специалистами. В работе предпринимается попытка классифицировать исследуемый пласт лексики, учитывая пути ее возникновения в русском и французском языках. Особое внимание уделяется номенклатурным единицам, построенным на основе греческих и латинских словообразовательных элементов.

Ключевые слова: терминология, терминосистема, этимология, заимствование, интернационализм. 
Современная косметология - это «научно-медицинская дисциплина, изучающая лечебную косметику, разрабатывающая средства и методы улучшения состояния лица и тела человека, изучающая методы диагностики, профилактики, лечения заболеваний и устранения косметических недостатков кожи, <..> а также осуществляющая проверку косметических средств, создаваемых и выпускаемых косметической промышленностью, на их безвредность» [2; 3].Косметология тесно связана с такими разделами медицины как дерматология, стоматология, хирургия, в которых латинские и латинизированные греческие элементы,как известно, составляют основу терминологической системы.Формируя медицинскую терминологию, они«взаимодействуют друг с другом, приобретают новые значения, вступают в новые сочетания, организуют новые модели[4]. Целью настоящего исследования является попытка изучить этимологию основных косметических терминов во французском и русском языках и определить роль греколатинских заимствований именно в данной области медицинской науки.

Собственно, сам термин «cosmétologie»/«косметология», как и большинство научных лексических единиц в медицинской номенклатуре, в обеих исследуемых языковых системах представляет собой сочетание греческих основ: косметикос «красота, искусство украшения» и -логия -«учение».Подобные слова, происходящие от латинских или греческих словообразовательных элементов, и в связи с этим, имеющие похожую форму в различных языках, составляют определенную часть в терминологической системе косметологии русского и французского языков. Это так называемые интернационализмы, которые выделяются в особый класс заимствованной лексики. В современной лингвистике под интернационализмами понимаются слова, совпадающие по своей форме и полностью или частично совпадающие по смыслу, они выражают понятия международного характера из области науки и техники, политики, культуры, искусства и функционируют в разных, прежде всего, неродственных языках[1]. Интернационализм наиболее приближен к требованиям, предъявляемым к идеальному термину, который должен быть по возможности однозначным и стилистически нейтральным [5]. В косметической номенклатуре интернационализмы занимают достаточно большойобъем. Однако, по сравнению с лексемами, составляющими номенклатуру других медицинских направлений, в косметологии не так многочисленны термины, построенные с помощью латинских и греческих морфем. Изисследуемых нами языковых единиц к лексике подобного рода относятся,существительные эмульсия/ émulsion, флюид / fluide, гель/ gel, база/ base, тон/ ton, мусс / тоиsse, лосьон/ lotionи др.Например, термин «эмульсия»,как и его французский аналог «émulsion»,имеет латинские корни (emulsumили emulsio- эмульсия, от глаголаemulgeo - доить, выдаивать). Но в русский язык слово попало через языкпосредник, которым в данном случае оказался французский. Термин «флюид»/ «fluide»в обоих языках происходит от латинского fluidus - жидкий. В русском языке в физической и химической науках он используется на протяжении многих веков, нодля международного косметологического обозначения текстуры специального крема стал употребляться только в ХХвеке с появлением соответствующего средства и, предположительно, под влиянием французского или английского языков, при этом, как правило, только в составе сложного слова «крем-флюид».

Интернационализм «gel» / «zель» происходит от латинского gelu - мороз, стужа; лёд; старческая слабость; окоченение. Со временем произошло расширение семантики слова, и с началом бурного развития химической и, в частности, косметологической науки в XVIII-XIX веках существительное «gel» во французском языке приобрело значение «substanceassezferme, élastiqueettransparente, résultantdel'évaporationd'unliquidecontenudansunesuspensioncolloïdale» / «достаточно густая, эластичная и прозрачная субстанщия, получаемая в результате выпаривания жидкости, содержащейся в коллоидной взвеси» [8]. Согласно лексикографическим 
данным, русский термин «гель» был заимствован из немецкого языка, полностью сохранив форму и значение [6].

Некоторые интернационализмы, имеющие «классическое»происхождение, со временем изменили исходную форму либо в обеих исследуемых языковых системах, либо только в одной из них. В качестве примера можно привести существительное «crème» / «крем», взятоеиз древнегреческого, где «chrisma» значило«мазь» (производное от chriō - умащаю, смазываю) [7]. Форма слова трансформировалась и, как и в рассмотренных выше примерах, в русский язык термин попал благодаря французам (вторая половина XVIII века) [6].К таким терминам можно отнести и существительные nyдpa/ poudre(от латинскогорulvis, pulveris- порошок), гоммаж/ gommage и эксфолиант / exfoliant (от латинскогоехfoliare - обрывать листья) [8].

В отличие от рассмотренных выше единиц, термин «бальзам» в русском языке почти сохранил форму оригинала (от латинского balsamum - бальзам, благовония), хотя был заимствован из немецкого(balsam) [6]. В французский язык данная лексема пришла непосредственно из латинского, но форма слова претерпела достаточно большие изменения, трансформировавшись в baume [bom] [8]. Следовательно, интернационализмом в отношении данных языковых систем этот термин не является.

Достаточно обширная часть терминов-интернационализмов в косметологии имеет английское происхождение: лайнер/ liner, пилинг / peeling, скраб / scrub, cmик/ stickи многие другие. При этом часто употребляемый термин мейк-an/ makeиранглийского происхождения интернационализмом назвать нельзя, так как, имея идентичную форму в исследуемых системах, он используется в разных значениях: во французском языке «тональный крем» или «крем-основа», в русском языке - в более общем значении «макияж». Гораздо более скромная роль в пополнении косметической терминосистемы принадлежит другим языкам. Например, из итальянского было заимствовано только слово маска / masque, из арабского - синонимы кайал, кхоль / kajal, kohl, из голландского - макияж / maquillage.

Интересно отметить, что в русской терминосистеме присутствуют слова французского происхождения, не употребляемые во французской терминологии. Например, существительное «тушь» происходит от французского touche «прикосновение; мазок», от toucher «трогать, касаться». В русский язык оно пришло из немецкого (отTusche) [6]. Термин «помада»был заимствован в XVIII в. из французского, где pommade восходит к латинскому ротит- «яблоко». Название обусловлено тем, что помадой сначала называли приготовленную из яблок лекарственную мазь. Древнеславянское происхождение имеют термины средство, масло, молочко, сыворотка, пенка, тени, румяна и т.д.

Во французской косметической номенклатуре также можно зарегистрировать большое количество французских терминов. Конечно, как правило, все они латинского происхождения, что связано с историей возникновения французского языка, но уже давно изменили свою графическую и фонетическую форму в соответствии с нормами французской языковой системы: huile(от латинскогоoleum- «масло»); beurre(от латинского bútyrum - «твердое масло»; savon(от латинского sapo, saponis- «мыло» и многие другие.

Во французской терминологии, по сравнению с русской, присутствует гораздо большее количество слов, заимствованных из английского и итальянского языков.

Проведенное исследование позволяет констатировать, что заимствование как способ обогащения словарного состава имеет большое значение для пополнения терминологического фонда косметологической науки французского и русского языков. Присутствие заимствованной лексики можно объяснить, прежде всего, международным характером деятельности косметической промышленности. Однако, если сравнить косметическую терминологию и терминологию, применяемую во всех остальных 
медицинских номенклатурах, можно, на наш взгляд, отметить две характерные особенности. Во-первых, терминосистема косметологической индустрии не настолько активно пополнялась и пополняется за счет прямого привлечения лексики и словообразовательных средств древнегреческого и латинского языков. Следствием этого является то, что в ней нет единообразия в межъязыковом плане и строгой научности, наблюдаемых в медицинской науке, где практически все специальные слова имеют схожие формы в различных языках благодаря своему «классическому» происхождению. Во-вторых, достаточно часто можно наблюдать примеры косвенного заимствования из латинского или греческого языков, их опосредованного участия в формировании термина, особенно данное замечание касается русских терминов. При этом многие интернационализмы, встречающиеся в рассматриваемой парадигме слов, имеют современное, как правило, английское или французское происхождение.

\section{$* * *$}

1. Бельчиков, Ю.А. Интернационализмы // Лингвистический энциклопедический словарь / Гл. ред. В.Н. Ярцева. - М.: Сов. энцикл., 1990. - С. 197.

2. Дрибноход, Ю.Ю. Косметология: учеб. пособие [Текст] / Ю.Ю. Дрибноход. - М.: Феникс, 2016. $800 \mathrm{c}$.

3. Ефремова, Т.Ф. Большой современный словарь русского языка [Текст] / Т.Ф. Ефремова. - М.: ACT, 2006. $-1168 \mathrm{c}$.

4. Полухина, О.Н. Ремпель Е.А., Роль греко-латинских заимствований в становлении российской медицинской терминологии [Электронный ресурс] / Режим доступа: https://medconfer.com/node/6018

5. Таранова, Е.Н. Структурно-семантические особенности терминологии женской косметики (на материале русского и немецкого языков): дис. канд. филол. наук [Текст] / Е.Н. Таранова. Белгород, 2010. - 208 с.

6. Многофункциональный многоязычный словарь [Электронный ресурс]. - Режим доступа: https://ru.wiktionary.org/wiki/Заглавная_страница

7. Школьный этимологический словарь русского языка [Электронный ресурс]. - Режим доступа: http://enc-dic.com/

8. TLF. Trésor de la langue française. Dictionnaire de la langue du XIX-e et XX-e s. - Paris: Gallimard, 1986 [Электронныйресурс]. - режимдоступа: http://www.cnrtl.fr/definition/gommage

\section{Федорова Г.А. \\ Трансформация фразеологических единиц в немецких и якутских публицистических текстах \\ Северо-Восточный федеральный университет им. М.К. Аммосова}

(Россия, Якутск)

doi: $10.18411 / l j-30-11-2017-28$

idsp: 000001:lj-30-11-2017-28

\section{Аннотация:}

В этой статье сравниваются трансформации фразеологических единиц, которые встречаются в немецких и якутских публицистических текстах. Теоретической основой послужили труды лингвистов, изучавших данную тему, а точнее работы Н.М. Шанского, К.Л. Шадрина, В.В. Горлова, Е. Ризель и других. Материалами исследования выступают газеты «SüddeutscheZeitung», «dieWelt», «derStandart», «Кыым», «Киинкуорат» за ноябрь 2016 года по май 2017 года. В общей сложности было просмотрено 103 статьи и отобрано 40 примеров в работе.

Ключевые слова: трансформация, фразеологическая единица, фразеологизм. 